\title{
The influence of the European CiViTAS ELAN project on development of a better and sustainable public transport in the City of Zagreb
}

\author{
D. Baric, L. Novacko \& H. Pilko \\ University of Zagreb, Faculty of Transport and Traffic Sciences, Croatia
}

\begin{abstract}
The CiViTAS Initiative is the EU response to the growing problems caused by traffic in European urban centres such as traffic congestion, noise, exhaust gases and difficult access to the city centre. The CiViTAS Initiative helps cities to test and develop an integrated set of measures for sustainable urban mobility. One of the projects is CiViTAS ELAN where five cities: Ljubljana, Gent, Zagreb, Brno and Porto are cooperating. The goal of this project is to improve the quality of life for citizens and to implement better solutions in urban transport by promoting and enhancing sustainable, clean and energy efficient ways of transport. It is funded by the FP7 Programme and total duration of the project is 48 months from 2008 to 2012. As a part of CiViTAS ELAN, the City of Zagreb wants to discourage the use of cars by making public transport and cycling as a more attractive alternative. CiViTAS highlights in Zagreb are: decrease of traffic congestion, improvement of quality, accessibility and attractiveness of public transport, switch to cleaner modes of public transport, lower environmental impact of city fleet, inclusion of the existing railway into the city's public transport system, improvement of cycling conditions and introduction of alternative modes of transport and mobility i.e. car pooling. The paper will present some measures and their results after three years of project implementation such as decreased congestion in pilot corridor along Savska street, decreased energy consumption and noise, improved public transport quality by purchasing 70 energy efficiency trams and 160 buses on gas or biodiesel, e-ticketing, inter-modal solutions, etc.

Keywords: CiViTAS ELAN project, sustainable public transport, city of Zagreb.
\end{abstract}




\section{Introduction}

European Commission is working to improve citizens' quality of life and strengthen the economy by promoting sustainable urban mobility and increased use of clean and energy efficient vehicles. New challenges such as climate change, energy policy, air quality legislation and the difficulties of tackling congestion have emerged in recent years. The objective now is to enhance mobility while at the same time reducing congestion, accidents and pollution in European cities [1]. Sustainable development of urban areas is covered by initiatives from various Community policies and programmes. White paper adopted by the European Council in 2001 (White paper - "European transport policy for 2010: time to decide") was sustainable development strategy where the Commission proposes some 60 measures aimed at developing a European transport system [2]. In 2009 the European Commission adopted the Action Plan on urban mobility which proposes twenty measures to encourage and help local, regional and national authorities in achieving their goals for sustainable urban mobility [3]. With the Action Plan, the European Commission presents for the first time a comprehensive support package in the field of urban mobility. White paper 2011 "Roadmap to a Single European Transport Area - Towards a competitive and resource efficient transport system" is a new strategy [4]. The European Commission adopted a roadmap of 40 concrete initiatives for the next decade to build a competitive transport system that will increase mobility, remove major barriers in key areas and fuel growth and employment. By 2050, key goals will include: no more conventionally-fuelled cars in cities, $40 \%$ use of sustainable low carbon fuels in aviation; at least $40 \%$ cut in shipping emissions, a $50 \%$ shift of medium distance intercity passenger and freight journeys from road to rail and waterborne transport, all of which will contribute to a $60 \%$ cut in transport emissions by the middle of the century.

In the field of urban mobility research, an extensive range of research, applied research and demonstration activities have been financed over recent years.

Current research, applied research and demonstration activities are implemented through the Seventh Framework Programme for Research and Technological Development. Research covers the fields of alternative motor fuels including their application in transport and urban mobility research including the next generation of vehicles, new mobility concepts, non-polluting modes of transport, demand management, and tools to support policy development and implementation. The CiViTAS Initiative ("City-VitalitySustainability", or "Cleaner and Better Transport in Cities") was launched in 2002 as a part of FP7 programme. Its fundamental aim is to support cities to introduce ambitious transport measures and policies towards sustainable urban mobility. The goal of CiViTAS is to achieve a significant shift in the modal split towards sustainable transport, an objective reached through encouraging both innovative technology and policy-based strategies. So far projects in 59 cities have been or are being supported. The City of Zagreb joined together with four other cities in the CiViTAS ELAN project "Mobilising citizens for vital cities". 


\section{The CiViTAS initiative}

\subsection{About CiViTAS initiative}

The CiViTAS Initiative helps cities to test and develop an integrated set of measures for sustainable urban mobility. CiViTAS cities take an integrated planning approach that addresses all modes and forms of transport in cities. They aim to demonstrate that it is possible to ensure a high level of mobility for all citizens, offer a high quality of urban space and protect the environment through sustainable mobility. It is this integrative approach based on innovation, collaboration, research and results-orientation that sets CiViTAS apart.

Within CiViTAS, eight thematic categories of measures have been identified as the basic building blocks of an integrated strategy for sustainable mobility: clean fuels and vehicles, collective passenger transport, demand management strategies, mobility management, safety and security, car-independent lifestyle, urban freight logistics, transport telematics. Each city chooses a set of mobility solutions from these building blocks according to their local priorities.

In the first phase of the project (2002 to 2006), 19 cities participated in four research and demonstration projects. In CiViTAS II (2005 to 2009), 17 cities participated across a further four projects. The initiative is currently in its third phase, CiViTAS Plus (2008 to 2013), and 25 cities are now working together on five collaborative projects. In total, almost 60 European cities have been cofunded by the European Commission to implement innovative measures in clean urban transport, an investment volume of well over EUR 300 million (Figure 1). But there are so-called demonstration cities as well. They are part of the larger CiViTAS Forum network, which comprises almost 200 cities committed to implementing and integrating sustainable urban mobility measures. This, in turn, represents 68 million citizens in 31 countries [5].

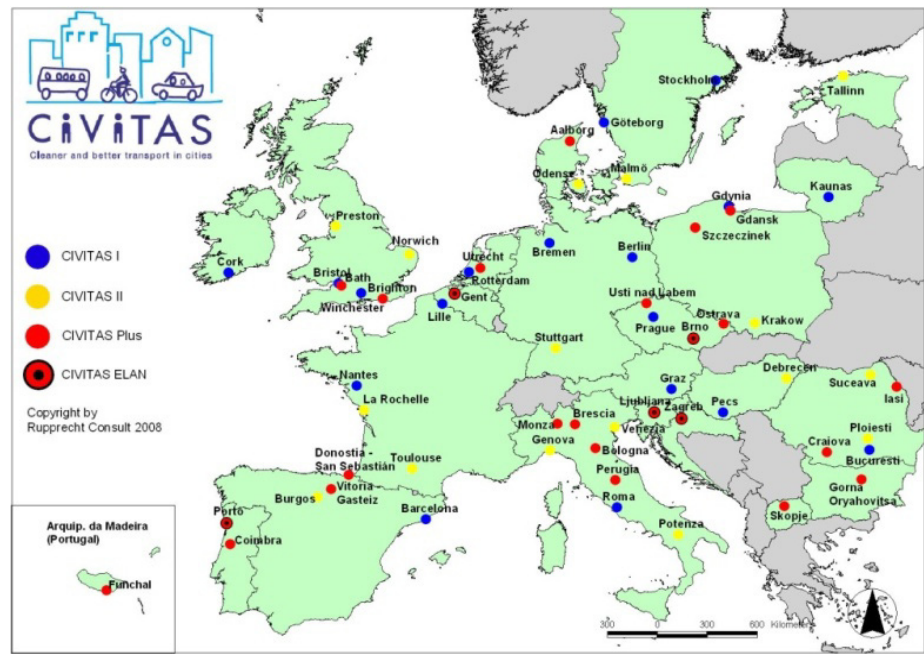

Figure 1: $\quad$ The CiViTAS cities. 


\subsection{CiViTAS ELAN project}

As part of the EU CiViTAS programme, the ELAN project takes an approach where "Putting the citizen first" is at the core of the work in the cities. In responding to citizens' needs, CiViTAS ELAN has identified headline objectives for each CiViTAS policy field (Table 1) [7].

Table 1: Headline objectives CiViTAS ELAN for each CiViTAS policy field.

\begin{tabular}{|c|c|}
\hline Policy field & Headline objectives \\
\hline $\begin{array}{l}\text { Alternative } \\
\text { fuels and } \\
\text { clean energy } \\
\text { efficient } \\
\text { vehicles }\end{array}$ & $\begin{array}{l}\text { - Increasing energy efficiency through comprehensive energy management and } \\
\text { innovative energy recovery/saving techniques } \\
\text { - Reducing dependency on fossil fuels by increasing use and production of } \\
\text { biofuels } \\
\text { - Increasing use of CNG } \\
\text { - Cleaning up local vehicle fleets through a mix of technologies/fuels } \\
\text { - Initiating local and European "green procurement" approaches }\end{array}$ \\
\hline $\begin{array}{l}\text { Collective } \\
\text { transport } \\
\text { services and } \\
\text { intermodal } \\
\text { integration }\end{array}$ & $\begin{array}{l}\text { - Implementing effective, high quality mobility solutions } \\
\text { - Integrating transport modes and local-regional public transport } \\
\text { - Giving priority to PT on the road, at intersections and (P\&R) interchanges } \\
\text { - Planning intermodal infrastructure with active public involvement }\end{array}$ \\
\hline $\begin{array}{c}\text { Demand } \\
\text { management }\end{array}$ & $\begin{array}{l}\text { - Preparing for a sustainable congestion charging scheme } \\
\text { - Establishing a public dialogue on pricing } \\
\text { - Returning public space to pedestrians } \\
\text { - Managing space to increase its quality and its use by sustainable modes }\end{array}$ \\
\hline $\begin{array}{l}\text { Influencing } \\
\text { travel } \\
\text { behaviour }\end{array}$ & $\begin{array}{l}\text { - Adopting a targeted mobility marketing approach } \\
\text { - Providing mobility management plans to major institutions } \\
\text { - Making walking and cycling more attractive } \\
\text { - Establishing a mobility dialogue with the citizens } \\
\text { - Providing high-quality mobility information to the citizens }\end{array}$ \\
\hline $\begin{array}{l}\text { Safe and } \\
\text { secure } \\
\text { mobility }\end{array}$ & $\begin{array}{l}\text { - Developing integrated and target-group specific safety and security strategies } \\
\text { - Increasing road safety (especially for vulnerable road users) } \\
\text { - Improving security in Public Transport }\end{array}$ \\
\hline $\begin{array}{l}\text { Innovative } \\
\text { mobility } \\
\text { services }\end{array}$ & $\begin{array}{l}\text { - Implementing flexible demand-responsive mobility services and agencies } \\
\text { - Developing car sharing concept further } \\
\text { - Providing a coordinated response to major events }\end{array}$ \\
\hline $\begin{array}{l}\text { Freight } \\
\text { distribution }\end{array}$ & $\begin{array}{l}\text { - Rationalising freight distribution } \\
\text { - Improving institutional cooperation on "freight" }\end{array}$ \\
\hline $\begin{array}{l}\text { Transport } \\
\text { telematics }\end{array}$ & $\begin{array}{l}\text { - Increasing the commercial speed of PT by giving priority } \\
\text { - Providing reliable traveller information } \\
\text { - Simplifying ticketing and integrating fares } \\
\text { - "Decongesting" corridors from polluting vehicles } \\
\text { - Introducing telematics for clean modes }\end{array}$ \\
\hline
\end{tabular}


The cities of Zagreb (Croatia), Ljubljana (Slovenia), Ghent (Belgium), Brno (Czech Republic) and Porto (Portugal) joined together in the CiViTAS ELAN project "Mobilising citizens for vital cities". They have agreed on the mission, "to 'mobilise' our citizens by developing with their support clean mobility solutions for vital cities, ensuring health and access for all". These cities face particular challenges such as fast motorisation, capacity problems in public transport, infrastructure renewal and rapidly changing cityscapes. These rapid changes create many opportunities for cities from both old and new Member States to learn from each other. Ljubljana, Brno and Zagreb represent cities from new Member States or accession countries with Ljubljana acting as the project coordinator.

\section{CiViTAS ELAN in Zagreb}

The city of Zagreb, nine hundred year-old city, is the capital and largest city of Croatia with more than 800,000 inhabitants on an area of $641.22 \mathrm{~km}^{2}$. Its flourishing economy and rising standard of living have been accompanied by a steep rise in the number of private cars beyond the city. Public transport consists of buses, trams, funicular and suburban trains. There are more than $200 \mathrm{~km}$ of bicycle trails, although a real network is still missing. The city centre boasts a lot of pedestrian areas, parks and green areas. As part of CiViTAS ELAN, Zagreb wants to restrict the use of cars where necessary, change citizens' travelling habits and improve links between different modes of transport to make public transport a more attractive alternative to the car [7].

\subsection{Target corridor}

The demonstration corridor has a length of approximately $3.5 \mathrm{~km}$ and extends from the Main Railway Station on the north along Savska cesta road towards the future "Sava-North" intermodal interchange (i.e. on the northern side of the Sava River) in the south (Figure 2). Along the Savska cesta road there are several faculties and two large student canteens, as well as a few large private companies which represent the significant 'corridor attractors'. The Savska cesta road is one of the most congested traffic arteries, with a large number of tram lines and personal vehicles sharing insufficient space. This results in slow traffic flow and frequent traffic jams. The existing traffic signalization, which is separating trams from rest of traffic, is often ignored. Parallel to Savska cesta road two tracks of the railway presently do not integrate with the city's public transport system, due to the fact that there are no stations on it now. The area where the future intermodal passenger terminal "Sava-North" is being planned is now partially used as a bus terminal, with a too small and inadequate interchange, which requires that passengers must cross a complicated single-level crossing to change from a bus to a tram. 


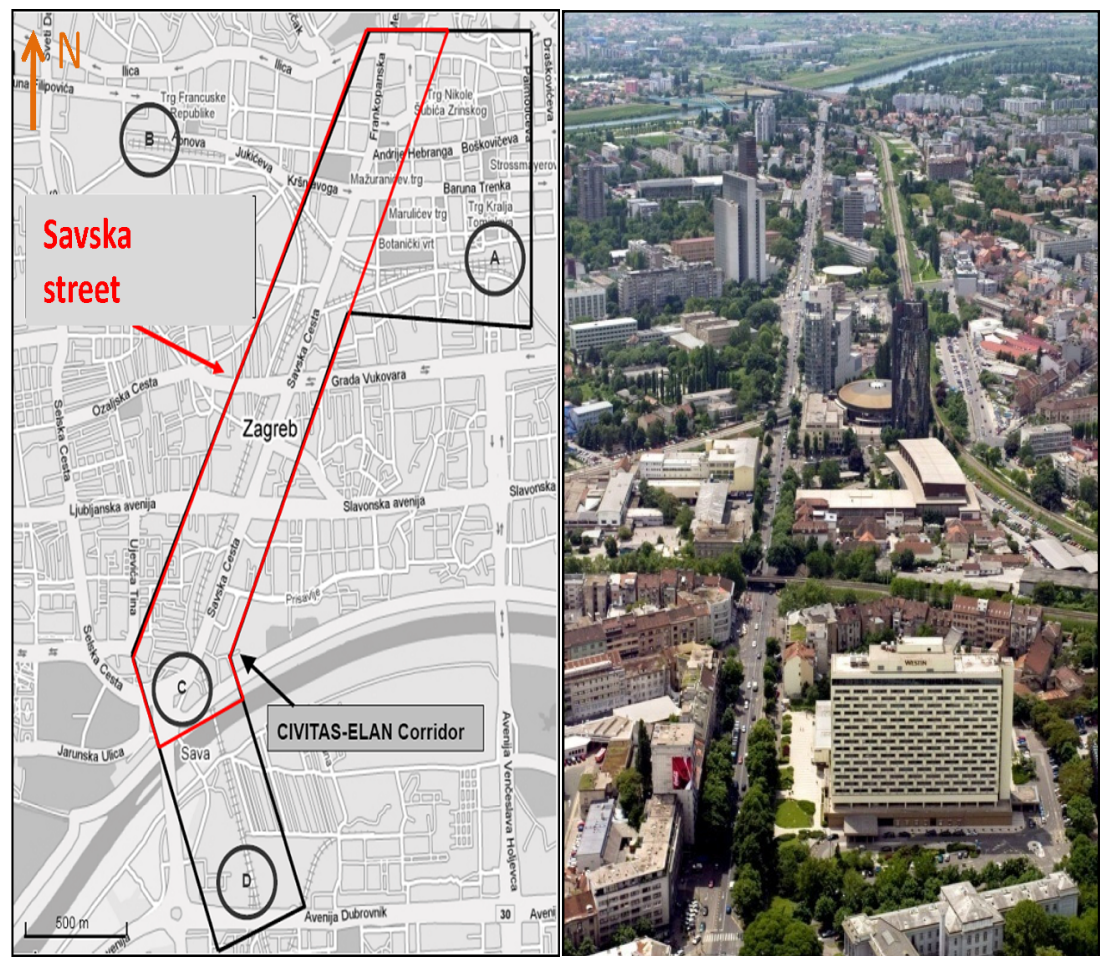

Figure 2: $\quad$ Target corridor Zagreb (A - Main Railway Station; C - New interchange 'Sava-North'; B - West Railway Station; D - New PT stop).

\subsection{Focus measures}

The high-level project objectives have been translated into major project goals, the specific outputs to be produced, and will be implemented by 68 measures. For each CiViTAS ELAN city a selection of focus measures has been made. The focus measures for the city of Zagreb are [6]:

- Intermodal high-quality mobility corridor;

- Energy recovery system for trams;

- Clean public transport strategies;

- Clean public fleet vehicles;

- Promotion of electronic PT tariff system;

- Study of congestion charging and dialogue on pricing;

- Freight delivery restrictions;

- Public transport priority and traveller information;

- Mobility management for large institutions;

- Improving cycling conditions;

- Comprehensive mobility dialogue and marketing; 
- Comprehensive safety and security strategies;

- Safety and security for seniors;

- Security improvement in public transport.

In table 2 the selection of focus measures for the City of Zagreb are shown.

Table 2: $\quad$ Focus measures for the City of Zagreb.

\begin{tabular}{|c|c|}
\hline Measure & Description \\
\hline $\begin{array}{l}1.3 \text { Energy } \\
\text { recovery system } \\
\text { for trams }\end{array}$ & $\begin{array}{l}\text { The modernization of the tram fleet in public transport presents a } \\
\text { comprehensive process which includes planning, procurement and } \\
\text { deployment of new vehicles. The work in all stages of this process involves } \\
\text { different stakeholders and their interactions. }\end{array}$ \\
\hline $\begin{array}{l}1.14 \text { Clean } \\
\text { public transport } \\
\text { strategies }\end{array}$ & $\begin{array}{l}\text { This measure aims at modernisation of the bus fleet in public transport and } \\
\text { supports the usage of alternative fuels in Croatia. }\end{array}$ \\
\hline $\begin{array}{l}1.15 \text { Clean } \\
\text { public fleet } \\
\text { vehicles }\end{array}$ & $\begin{array}{l}\text { Zagreb aims to make its fleet of public transport vehicles more sustainable by } \\
\text { introduce energy-efficient vehicles and raising the share of clean fuels in its } \\
\text { fleet. }\end{array}$ \\
\hline $\begin{array}{l}\text { 2.6 Promotion of } \\
\text { electronic PT } \\
\text { tariff system }\end{array}$ & $\begin{array}{c}\text { The newly installed electronic PT tariff system includes new "smart card" } \\
\text { technology and data base management and presents innovative technology in } \\
\text { public transport. }\end{array}$ \\
\hline $\begin{array}{l}\text { 3.2 Study of } \\
\text { congestion } \\
\text { charging and } \\
\text { dialogue on } \\
\text { pricing }\end{array}$ & $\begin{array}{l}\text { The detailed analysis of different technological solutions for congestion } \\
\text { charging will provide the City of Zagreb with "blueprints" for the future } \\
\text { implementation. }\end{array}$ \\
\hline $\begin{array}{l}\text { 7.4 Freight } \\
\text { delivery } \\
\text { restrictions }\end{array}$ & $\begin{array}{l}\text { Considering the fact that the new and more restricted policy has to be } \\
\text { introduced in order to decrease the number of delivery vehicles in the city } \\
\text { centre during the day time period, this measure brings a high risk of failing. } \\
\text { Thus, detailed and continuous analysis of the implementation process will } \\
\text { enable early detection of measure barriers. }\end{array}$ \\
\hline $\begin{array}{c}8.2 \text { Public } \\
\text { transport priority } \\
\text { and traveller } \\
\text { information }\end{array}$ & $\begin{array}{l}\text { A strong ITS nature of this measure has encouraged to take a closer look at } \\
\text { the implementation process of this measure. This is the first time that an ITS } \\
\text { solution related to the public transport will be demonstrated in real-life } \\
\text { situation so we are highly motivated for analysing the development process } \\
\text { and impact of this measure. }\end{array}$ \\
\hline
\end{tabular}

\subsection{Partners}

The project partners are well aware of the crucial importance of a citizen-centred approach. Various non-governmental, citizen-driven organisations are full partners in CiViTAS ELAN and are in charge of carrying out concrete measures. They provide direct links between the CiViTAS community and those working at the local grassroots level. The project partners on in the City of Zagreb are:

- City of Zagreb;

- Faculty of Transport and Traffic Engineering;

- Zagreb Holding - Department "Cistoca" (waste disposal company);

- Zagreb Holding - Department "ZET” (Zagreb Electric Tram company);

- Croatian abbreviation for Sustaining Community Development;

- Croatian Railways Infrastructure - Development and Investment;

- $\quad$ BICIKL (NGO My Bike). 


\section{Results after three years project period}

Since the beginning of the project in late 2008 the results are visible in public transport and information and communication with citizens.

The city of Zagreb has implemented a new e-ticketing scheme in trams and buses and launched a study on an inter-modal passenger terminal that confirmed that it has been welcomed by citizens. The city also strives to make public transport cleaner and more energy efficient. Zagreb has introduced 70 energyefficient low-floor trams, 100 low-floor buses on bio-diesel and 60 busses on gas. It is now running busses and lorries of its waste management fleet on biodiesel, and trained drivers and personnel to use and maintain the new vehicles.

Zagreb has invested in the promotion of cycling and strengthened information sharing and mobility dialogue with citizens. Exchange with citizens at the early stages of the project revealed that citizens share the concerns about the current transport situation and are ready to get involved in finding solutions.
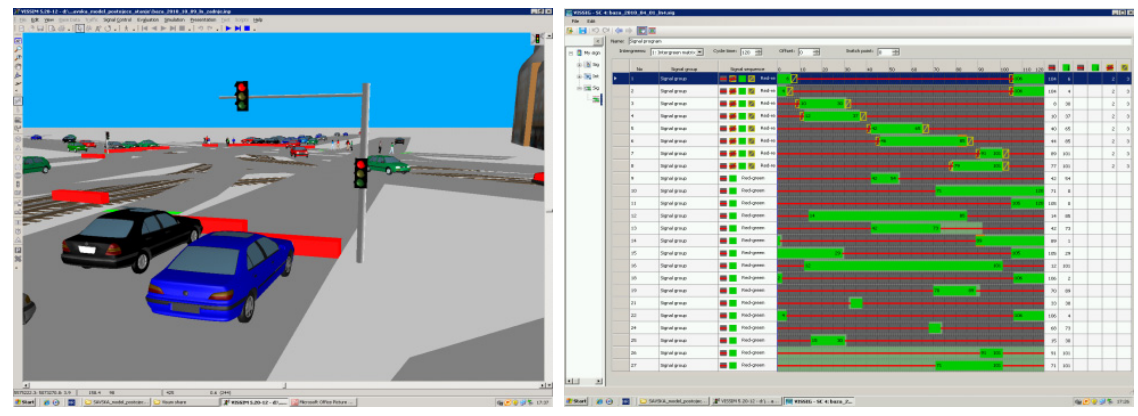

Figure 3: $\quad$ Simulation in PTV-VISSIM software.

The traffic condition model on the Savska Corridor has been developed in VISSIM software for micro-simulation of the PTV Vision (Figure 3). For this purpose, the necessary data were collected in order to create a high-quality model that will simulate the behaviour of passenger car users and public urban transport. Measurements were carried out in situ and included traffic counts at all corridor intersections, recording of public transport vehicle routes by means of GPS devices (running speed, dwell times), and the obtained data were entered into the traffic model [8]. Future plan is to give priority to public transport at all intersections and results after model implementation on only 3 relatively isolated intersections which were chosen are:

- Average tram travel time through the corridor: decrease of $7.24 \%$.

- Tram line 17 - through the whole corridor:

- Average travel time through the corridor: decrease of $3.90 \%$.

- Average travel speed: increase of $5.40 \%$. 
A simulation model of the present traffic situation will serve as a baseline to assess future developments and evaluate different interventions.

\section{Table 3: The expected results of some measures after full project} implementation

\begin{tabular}{|c|c|}
\hline Measure & greb expects the measure will: \\
\hline $\begin{array}{l}\text { Energy } \\
\text { recovery } \\
\text { system for } \\
\text { trams }\end{array}$ & $\begin{array}{l}\text { - Decrease electricity consumption and noise levels; } \\
\text { - Increase the accessibility of public transport; } \\
\text { - Increase the attractiveness of travelling by tram. }\end{array}$ \\
\hline $\begin{array}{l}\text { Clean public } \\
\text { transport } \\
\text { strategies in } \\
\text { the bus } \\
\text { network }\end{array}$ & $\begin{array}{l}\text { - Harmonise public transport vehicles with European environmental standards; } \\
\text { - Replace some of the fuel consumption in public transport fleet with } \\
\text { alternative fuels; } \\
\text { - Develop clean fuel technology in Croatia; } \\
\text { - Reduce particulates and } \mathrm{CO}_{2} \text { emissions; } \\
\text { - Reduce the level of noise }\end{array}$ \\
\hline $\begin{array}{l}\text { Clean public } \\
\text { fleet vehicles }\end{array}$ & $\begin{array}{l}\text { - Harmonise the city's fleet with European environmental standards; } \\
\text { - Develop clean fuel technology in Croatia; } \\
\text { - Reduce particulate matters and } \mathrm{CO}_{2} \text { emissions of CISTOCA fleet; } \\
\text { - Decrease noise emissions of the waste disposal fleet. }\end{array}$ \\
\hline $\begin{array}{l}\text { Promotion of } \\
\text { electronic PT } \\
\text { tariff system }\end{array}$ & $\begin{array}{l}\text { - Make regular travel easier, more efficient and user-friendly; } \\
\text { - Increase the number of public transport users and commuters; } \\
\text { - Introduce consumers to electronic ticketing; } \\
\text { - Unify the tariff system for all providers of public transportation; } \\
\text { - Contribute to a shift towards sustainable modes. }\end{array}$ \\
\hline $\begin{array}{l}\text { Study of } \\
\text { congestion } \\
\text { charging and } \\
\text { dialogue on } \\
\text { pricing } \\
\end{array}$ & $\begin{array}{l}\text { - Increase knowledge and acceptance of stakeholders in terms of congestion } \\
\text { charging and urban road pricing; } \\
\text { - Develop a clear picture of the challenges and possibility to introduce } \\
\text { congestion charging; } \\
\text { - Develop recommendations on how to implement congestion charging. }\end{array}$ \\
\hline $\begin{array}{l}\text { Public } \\
\text { transport } \\
\text { priority and } \\
\text { traveller } \\
\text { information }\end{array}$ & $\begin{array}{l}\text { - Increase the average speed of public transport vehicles, notably during rush } \\
\text { hours; } \\
\text { - Decrease noise and pollution levels; } \\
\text { - Improve mobility for public transport vehicles by giving them traffic light } \\
\text { priority at intersections; } \\
\text { - Reduce traffic jams; } \\
\text { - Save public transport costs thanks to a decreased need for vehicles and } \\
\text { reduced circulation time; } \\
\text { - Contribute to an overall increase of patronage in public transport by } 6 \% \text {. }\end{array}$ \\
\hline $\begin{array}{l}\text { Mobility } \\
\text { management } \\
\text { for large } \\
\text { institutions }\end{array}$ & $\begin{array}{l}\text { - Increase the number of passengers/cars by organising common journeys; } \\
\text { - Increase cycling by offering "test bicycles" to employees; } \\
\text { - Reduce congestion; } \\
\text { - Reduce level of air pollution and noise; } \\
\text { - Increase average number of passengers in cars by } 20 \% \text {; } \\
\text { - Increase the number of people commuting by alternative modes by } 10 \% \text {. }\end{array}$ \\
\hline $\begin{array}{l}\text { Improving } \\
\text { cycling } \\
\text { conditions }\end{array}$ & $\begin{array}{l}\text { - Increase the number of students regularly using bicycles from } 10-20 \% \text {; } \\
\text { - Increase the number of city employees commuting by bicycle from } 3-10 \% \text {; } \\
\text { - Increased public awareness about the benefits of a sustainable transportation } \\
\text { system; } \\
\text { - Foster enforcement and promote mutual respect of mobile citizens; } \\
\text { - Strengthen the integration between cycling and public transport; } \\
\text { - Reduce } \mathrm{CO}_{2} \text { by } 5 \% \text {, air pollutants and transport related noise. }\end{array}$ \\
\hline
\end{tabular}


Crucial for city is to inform and interact with citizens. The Info-point, an old refurbished tram situated in front of Technical museum is a source of information for Zagreb citizens, but also visitors and tourists. It is open five days a week and continuously attracts visitors. Brochures, leaflets and other information is available, visitors can leave their comments in the notebook or ask questions related to project and mobility. "Wednesdays in tram" are organised in the Info-point related to project measures, but also other mobility issues. One of the target groups are citizens living in local communities along the project's demonstration corridor. Meetings within community boards have been organized and citizens expressed the interest for such interactions.

The expected results of some measures after full project implementation are shown in table 3.

\section{Consideration remarks}

With CiViTAS ELAN, the city of Zagreb increase the modal share of walking and cycling, support innovative freight delivery solutions, implement innovative demand management, and increase the use of cleaner and energy-efficient vehicles. The project enhance overall road safety and reduce air pollution.

In addition to the implementation of concrete clean and sustainable urban transport solutions, CiViTAS ELAN mobilise people in physical, political and societal terms. Responding to citizens' demands constitutes better governance and will improve the quality of public transport. As a policy-driven project led by impact and process evaluation, the city of Zagreb and other ELAN cities will significantly contribute to major national, EU and global policy processes and motivate cities throughout Europe to follow their lead.

Zagreb is already able to share project findings, experiences and lessons learnt with other towns in Croatia that are keen to follow the capital's example.

\section{References}

[1] http://ec.europa.eu/transport/index_en.htm

[2] White paper: European transport policy for 2010: time to decide, Luxembourg: Office for Official Publications of the European Communities, 2001.

[3] Action Plan on urban mobility [COM(2009) 490].

[4] White paper: Roadmap to a Single European Transport Area - Towards a competitive and resource efficient transport system, COM(2011) 144.

[5] http://www.civitas.eu/index.php?id=69

[6] Description of Work Annex I, Seventh Framework Programme, Mobilising citizens for vital cities, CiViTAS ELAN, 2008.

[7] http://www.civitaszagreb.hr

[8] Novačko, L., Barić, D., Petrović, M.: Improvement of Mobility in the City of Zagreb by Implementation of Civitas ELAN Project, MOBILITA '11, $11^{\text {th }}$ International Scientific, Slovenska technicka univerzita $\mathrm{v}$ Bratislave, 2011, 73-79. 